\title{
56. BASIC FEATURES OF THE BLACK SEA LATE CENOZOIC HISTORY BASED ON THE RESULTS OF DEEP-SEA DRILLING, LEG 42B ${ }^{1}$
}

\author{
M. V. Muratov, ${ }^{2}$ Y. P. Neprochnov, ${ }^{3}$ D. A. Ross,${ }^{4}$ and E. S. Trimonis ${ }^{3}$
}

\section{INTRODUCTION}

The Black Sea is of special interest to geologists and geophysicians because of its unique deep structure and its geological environment. Its connection with the Mediterranean Sea through the relatively narrow and shallow-water Bosporus Strait was repeatedly interrupted causing sharp changes in the hydrological and hydrochemical regimes, in the fauna, and in sedimentation conditions. The main objectives of the DSDP Leg 42B were to obtain a complete Pleistocene stratigraphic section, to collect information concerning the association of the Black Sea with the Mediterranean, and to determine the basic signs of the diagenetic alteration of organic matter. It was also hoped that the drilling would solve a number of particular questions concerning geology, geophysics, geochemistry, biostratigraphy and other fields, and aid in a reconstruction of the Black Sea geological history.

\section{GEOLOGICAL AND GEOPHYSICAL SETTING}

There were three major cycles in the tectonic development of the Euro-Asia Mediterranean belt, where the Black Sea is located (Muratov, 1972). The first cycle occurred in the late Precambrian, when the folded basement between the old Eastern-European and African platforms was formed. During the second cycle, the upper Proterozoiclower Paleozoic folded basement was covered by platformtype sediments. The third cycle of tectonic development occurred in Mesozoic-Cenozoic time. During one of the stages of this cycle the development of the Alpian folded zone took place and the Black Sea basin emerged. At present the basin is framed by folded structures to the north, northeast, south, and southwest; to the northwest it borders on the Epihercynic platform, which forms part of the Black Sea shelf between the Balkan Peninsula coast and the Crimea.

Seismic investigations have shown a rather thick complex of sediments (12-14 km) in the Black Sea. The uppermost $1-2 \mathrm{~km}$ is characterized by seismic wave velocities of 1.6 to $1.8 \mathrm{~km} / \mathrm{sec}$; the second part, of about 3 to $5 \mathrm{~km}$ thickness, has velocities exceeding $3 \mathrm{~km} / \mathrm{sec}$; and the lower, third part, from 2 to $8 \mathrm{~km}$ thickness, has velocities of 4 to $4.5 \mathrm{~km} / \mathrm{sec}$. The upper part is proposed as probably corresponding to the young Pliocene-Quaternary sediments (The Earth's Crust. . . , 1975).

\footnotetext{
${ }^{1}$ Woods Hole Oceanographic Institution Contribution No. 4037.

${ }^{2}$ Geological Institute, Academy of Sciences, U.S.S.R

${ }^{3}$ P. P. Shirshov Insstitute of Oceanology, Academy of Sciences, U.S.S.R.

'Woods Hole Oceanographic Institution, Woods Hole, Massachusetts.
}

During investigations that preceded the deep-sea drilling, Black Sea sediments that were deposited during the past 25-30 thousand years have been recovered by piston coring. Deep-sea late Quaternary sediments of the Black Sea consist of three stratigraphic horizons that differ sharply in their lithology (Arkhangelsky and Strakov, 1938; Degens and Ross, 1974).

The youngest sediments (commonly called Unit 1) are mainly a nannofossil ooze which has a $\mathrm{C}^{14}$ age of about 3000 years at its base. Dark sapropelic sediments are found below them (Unit 2), which were formed from 3 to 9 thousand years ago. Unit 3 , a mixture of terrigenous mud, silt, and sand, was not completely cored.

\section{LITHOSTRATIGRAPHIC SECTIONS RECOVERED AT LEG 42B DRILL SITES}

Black Sea late Cenozoic sediments were recovered by drilling and continuous coring during Leg 42B of Glomar Challenger. At Site 379 in the eastern part of the basin, a considerable thickness of Pleistocene strata was obtained without reaching their base. Near the Bosporus two sites were drilled on the continental slope at depths of 2115 and 1750 meters. They obtained 1073.5 meters (Holes $380 / 380 \mathrm{~A}$ ) and 503.5 meters (Site 381 ), respectively, of bottom sediments (Figure 1).

At Site 379 (Figure 2), the upper two units (sampled by piston cores) were not recovered by drilling. The sedimentary units from this site begin at Unit 3 and are divided into nine units. The bulk of the sediments is terrigenous greenish gray and dark gray muds. Differences in terrigenous material, grain size, sediment texture, content of biogenic components, and other factors enable the division of the terrigenous strata into the separate units. Units 3,6 , and especially 8 contain numerous turbidites, and the content of biogenic components is relatively high in Units 4, 5, and 7. There are also intervals enriched in organic matter. Unit 9 is noticeably enriched in carbonate matter and has periodically repeated calcite layers.

The sediments from Holes 380/380A (Figure 3) can be divided into five large independent units. Unit $\mathrm{I}$ is composed of terrigenous muds, silts, and sands, and they differ from each other in a similar manner as those from Site 379. Unit II contains sediments of different composition and genesis; terrigenous muds and clays alternate with the interbeds of dolomite, calcite, siderite, and aragonite, and the sediments contain more pelitic fractions that Unit I. The mineral composition of the terrigenous components in Units I and II has many similarities; these include the predominance of illite in the clay portion. Unit III is mainly a seekreide and is clearly distinguished from other units by its lithology. The cyclic character of sedimentation 


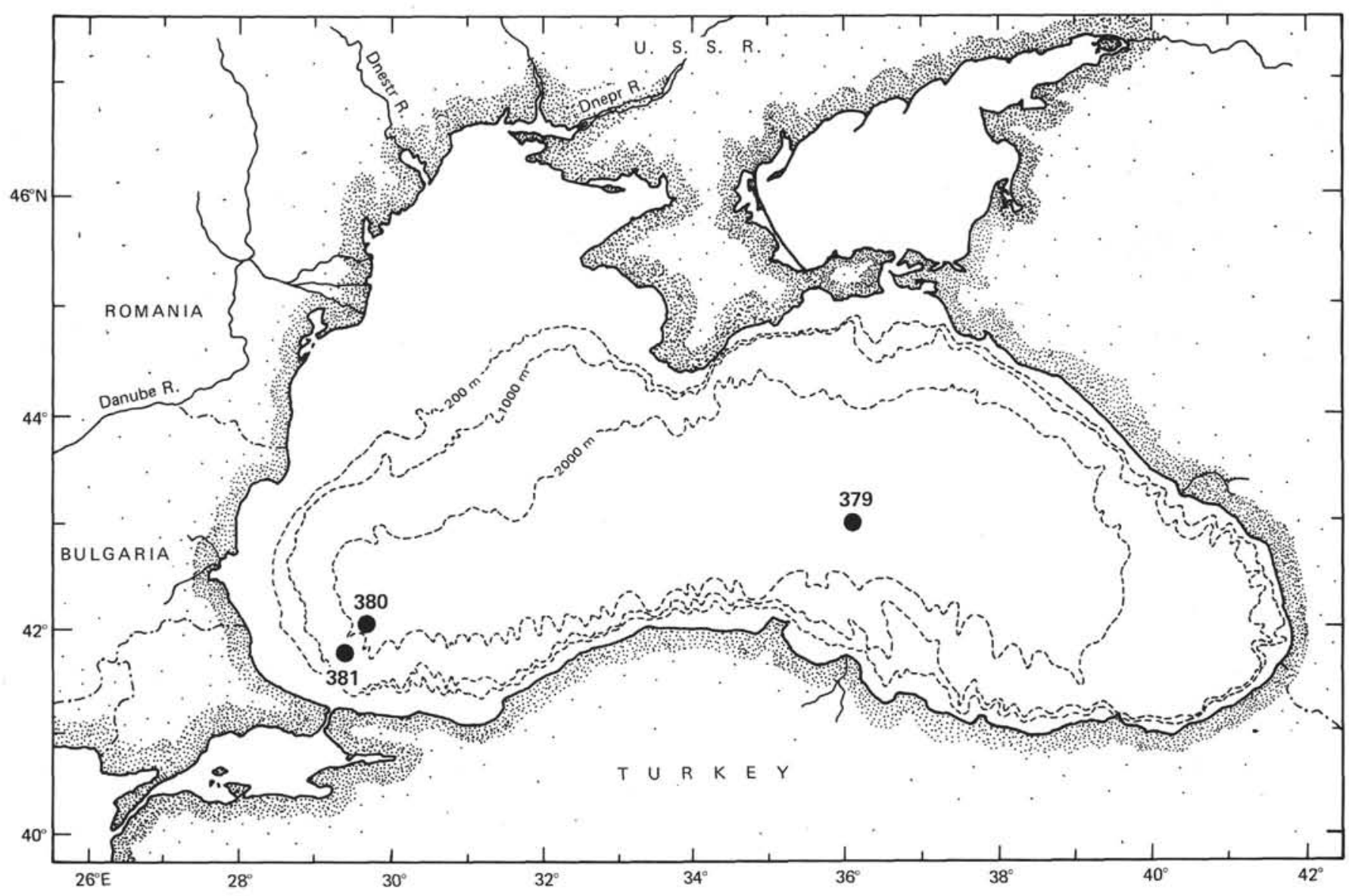

Figure 1. Leg $42 B$ drill sites.

expressed by the alternation of clays and calcite laminae is a characteristic feature of this unit. The clay fraction contains high quantities of montmorillonite and lesser amounts of kaolinite and chlorite as compared to the overlying muds. Unit IV differs noticeably in its lithology. In the upper part, laminated clays enriched in different complexes of diatoms predominate. Unit IV a has interbeds of siderite, and Unit IV has dolomite interbeds; calcite and aragonite are found at different levels. Unit $I V_{d}$ is a breccia. In general, the quantity of clayey material in this unit decreases from top to bottom, inversely to that of carbonate material. Many intervals are enriched in organic matter. The lowest division, Unit V, is a black siltstone with interbeds of dolostones and zeolites.

Site 381 (Figure 4) could be divided into 11 units, but again, the upper two were not present. Seekreide analogous to the cyclic carbonates in Unit III (Holes 380/380A) was found under terrigenous muds and clays of Unit 3 . The content of organic matter gradually increases towards the bottom of the section. Unit 8 is brecciated sediment with sand, dolomite, and mollusc detritus. In Unit 9 laminated siltstones alternate with fine sandy interbeds. The sediments do not contain carbonate matter and are enriched in organic material. Below them a brecciated interval is again found, but the lowest unit is mainly olive-gray finely laminated siltstones with interbeds of siderites.

\section{CORRELATION AND AGE OF SEDIMENTS}

Chronostratigraphic correlation of the lithological units from the three sites is a rather complicated problem (see
Ross, this volume). This complexity is linked with the relatively rare indigenous marine fossils and abundant reworked forms in the bottom sediments. Several investigations have reached different conclusions (see, for example, Stoffers et al., this volume; Hsü, this volume, "Stratigraphy of the Lacustrine..." and Correlation of Black Sea Sequences...'). To find synchronous horizons, cirteria such as palynological analysis (Traverse, this volume); estimation of different microfossils (Percival, this volume); diatoms (Jouse and Mukhina, this volume; Schrader, this volume); benthic foraminifers (Gheorghian, this volume); as well as comparisons of lithology, were used.

The palynological analyses were useful in correlating the terrigenous strata of the sediments from Holes 379A and 380 . On the basis of maximum and minimum curves reflecting the ratio of steppe to forest pollen, basic epochs of glacials and interglacials were determined. It has not yet been clearly indicated which epochs these are, nor have they been correlated to any standard stratigraphic correlation scheme. In the lower parts of Site 380 (Core 80), as well as in Units 9, 10, and 11 (Site 381), warm-loving mountainous species was identified, and can be used for correlation between the sites. Most of the fossils found give more information about modifications in the sedimentation environment, than about the sediment age. Only in rare instances can one use them for chronostratigraphy purposes.

Among the nannofossils only the following indigenous species are identified: Emiliania huxleyi, Gephyrocapsa caribbeanica, and Braarudosphaera bigelowi (Percival, 


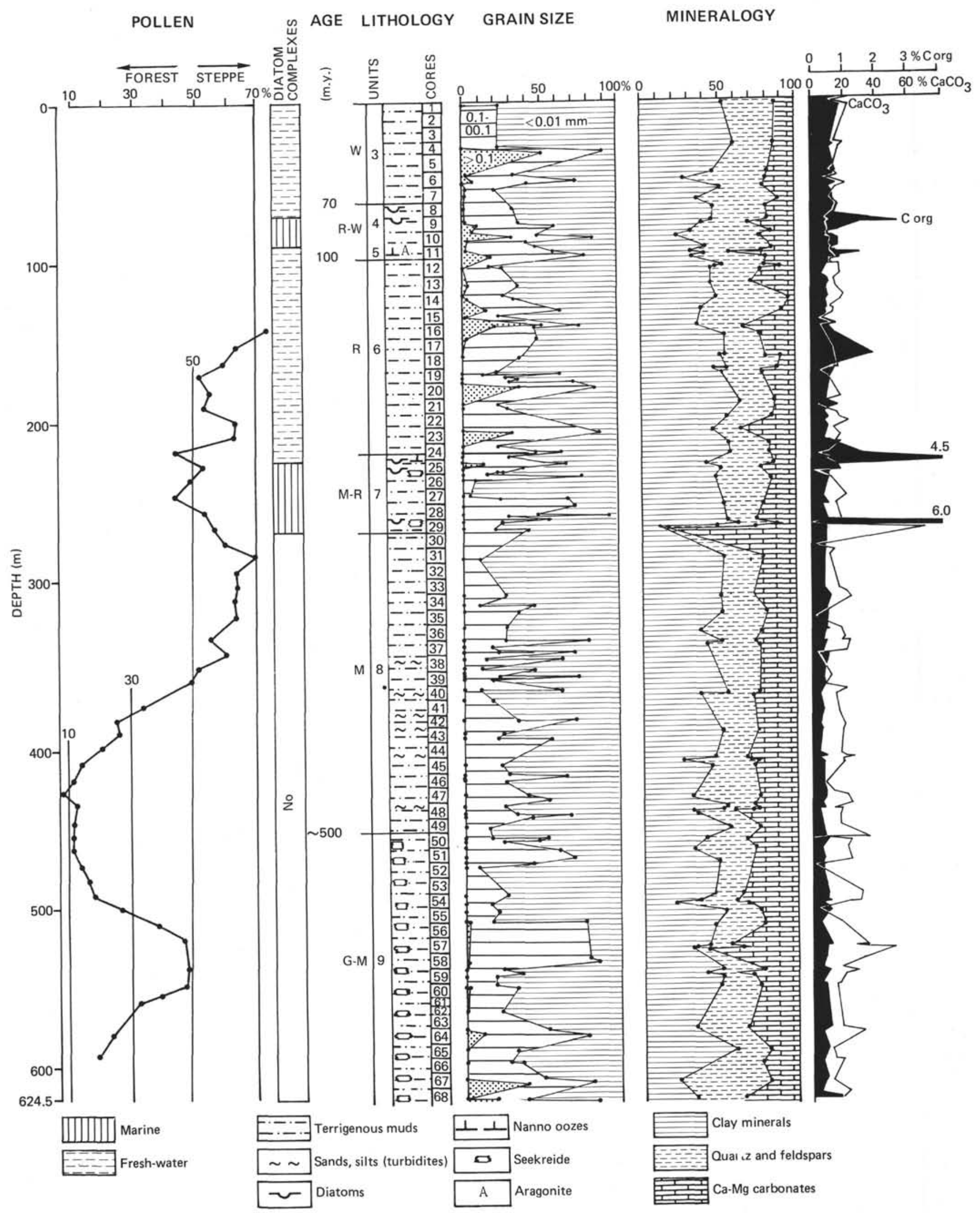

Figure 2. Lithostratigraphic section, Hole 379A. 


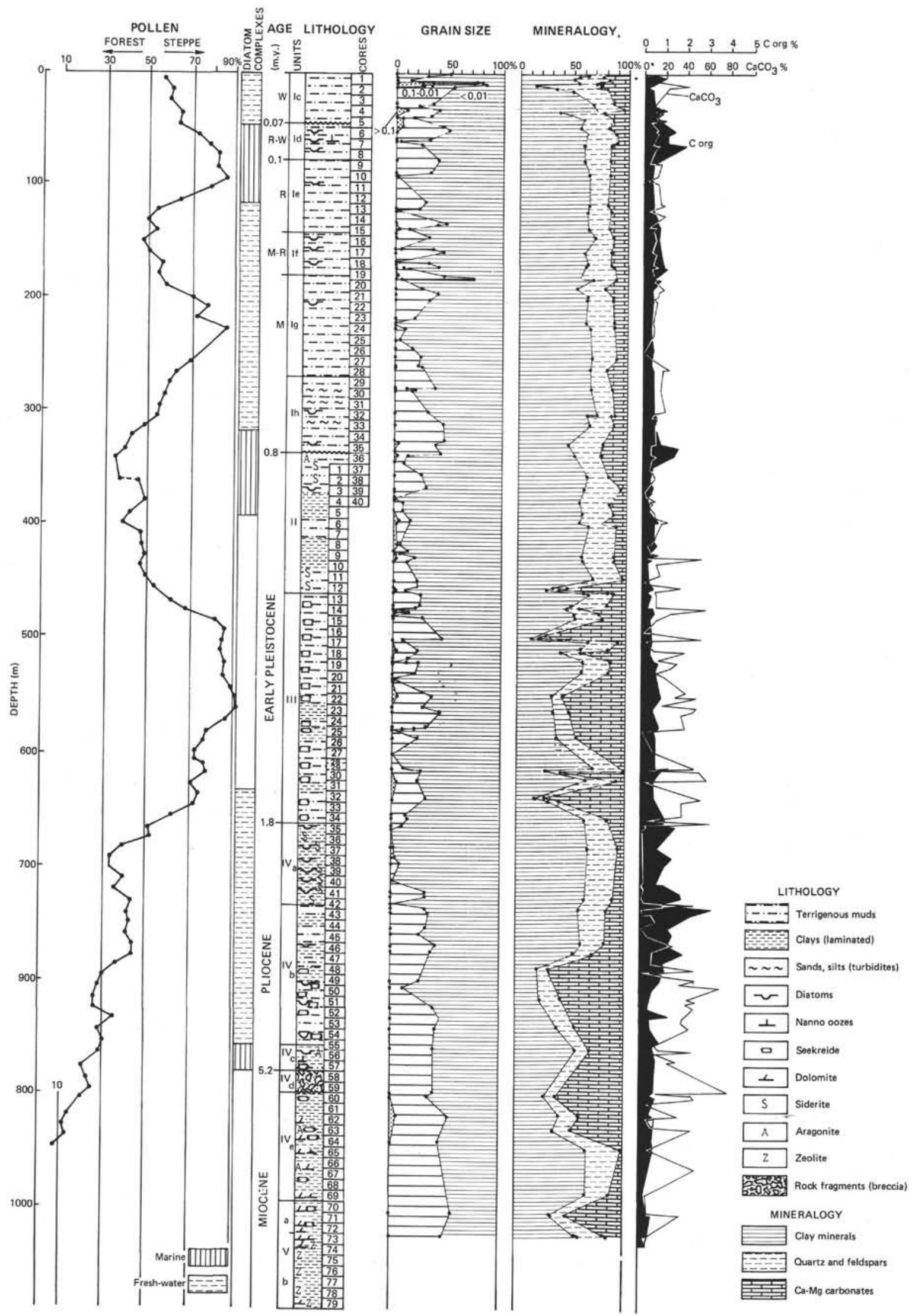

Figure 3. Lithostratigraphic section, Holes 380/380A. 

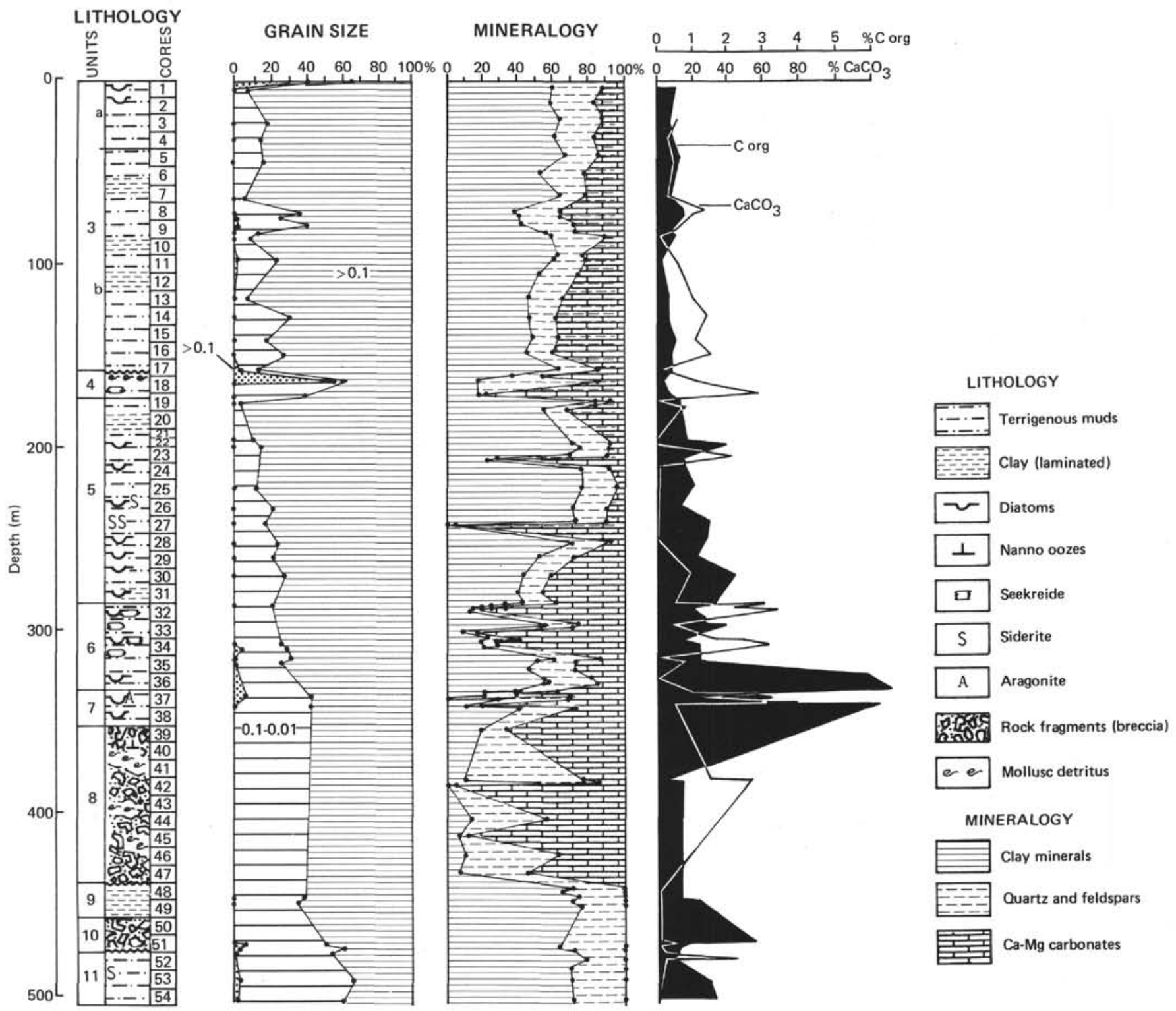

Figure 4. Lithostratigraphic section, Site 381.

this volume), as well as Gephyrocapsa oceanica (Shumenko, personal communication). The sediments of Unit 3 (Site 379) are probably correlative with those of Unit Ic (Site 380), since both units contain a Gephyrocapsa caribbeanica flora. Similarly, a Braarudosphaera flora in Unit 7 (Site 381) correlates with an analogous flora in Unit $\mathrm{IV}_{\mathrm{c}}$ from Site 380.

Intervals enriched in diatoms were found at all sites. Marine complexes of diatoms (Actinocyclus, Raphoneis, Hermesinum, Archaeomonadacea) were encountered in Unit IV $\mathrm{V}_{\mathrm{e}}$ (Holes 380/380A) and in Units 6 (the lower part) and 7 (Site 381); they probably correlate with each other. The probable age of these sediments is early Pliocene, since similar diatom complexes are known from Pontic deposits of the Taman and Kerch Peninsulas (Jouse and Mukhina, this volume). Marine brackish diatoms from Unit 4 (Site 379) correlate with the diatom complex in Unit $\mathrm{Id}_{d}$ (Site 380) and diatoms from Unit VII (Site 379) with those of Unit If (Site 380 ). Fresh-water and slightly brackish-water diatoms in Unit III (Site 380) are comparable with the diatom complex of Unit 4 (Site 381).
A large quantity of dinoflagellates called "'bag 51" was found in sediments containing fauna of fresh-water ostracodes and fresh-water diatoms. An example of this dinoflagellate species occurrence was at Site 380 (Core 39), i.e., where the sediments became turbidites, and at Site 379 (Core 51), where there is also a similar change in lithology. This phenomenon may be used for correlation purposes. The lowest discovery of dinoflagellate " $b a g$ 51" coincides with the end of the chemogenous carbonate sedimentation, and the beginning of the mainly terrigenous mud deposition.

Other characteristic lithological signs that may be correlated are interbeds of siderite in Unit $\mathrm{IV}_{\mathrm{a}}$ (Site 380) with those in Unit 5 (Site 381), brecciated horizons in Site 380 (Unit $I_{\mathrm{d}}$ ), and those from Site 381 (Unit 8).

Based on the present stage of investigations, and using the above criteria, the most probable chronostratigraphic correlation of the three Black Sea sites is shown in Figure 5.

The brecciated sediments at Holes $380 / 380 \mathrm{~A}$ and 381 indicate a sedimentary hiatus of unknown duration. The underlying sediments are close to late Miocene age. This assumption is based on the observation of complexes of 


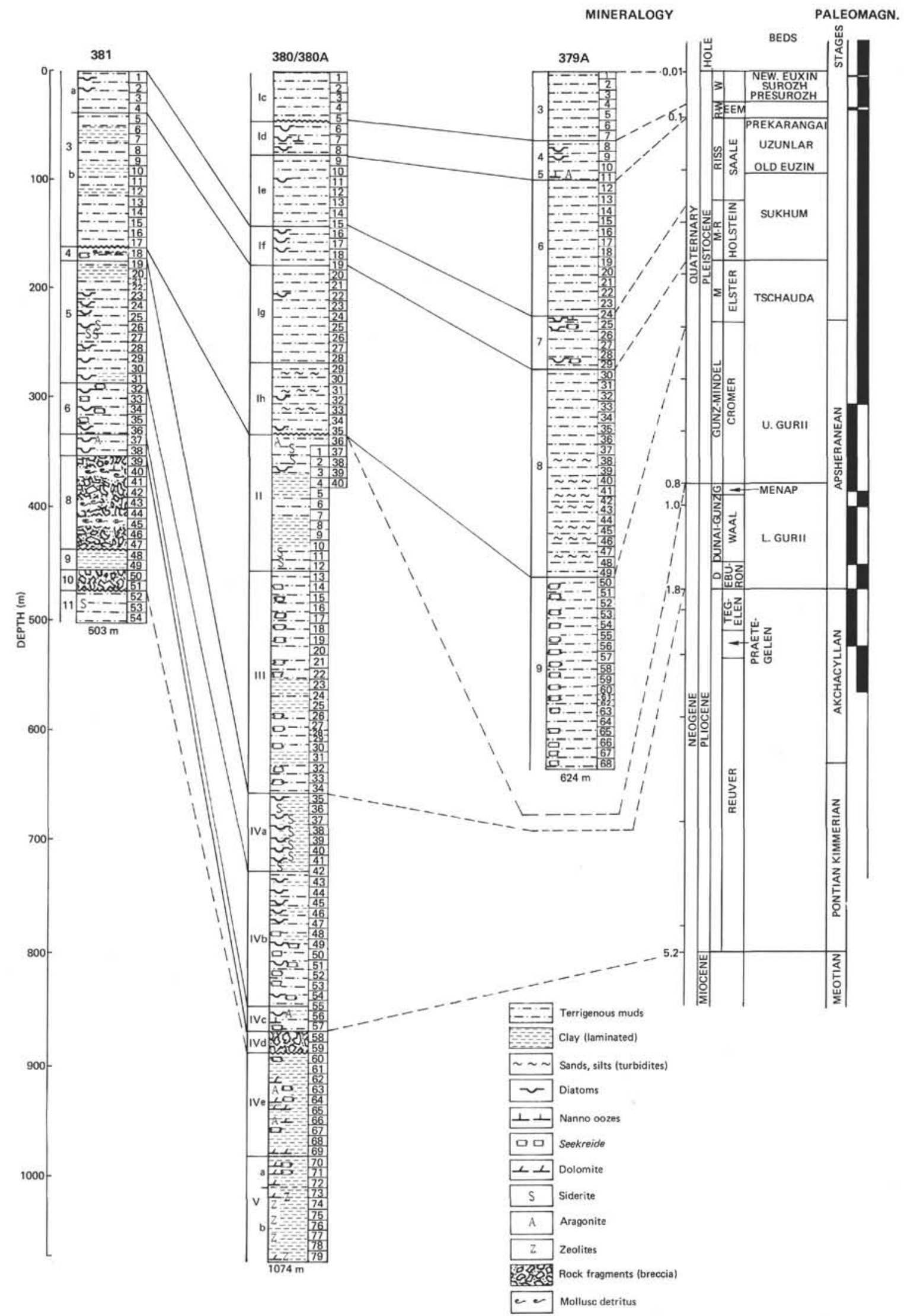

Figure 5. Correlation and suggested ages of Black Sea sediments cored during Leg 42B. 
benthic foraminifers which Gheorghian (this volume) considers to be typical of Sarmathian sediments in the Paratethys basins. Moreover, in the lower parts of Sites 380 and 381 an Engelhardtia flora was found, which had disappeared during the upper Miocene in northwestern Europe, as well as in the Mediterranean Europe, which is more or less synchronous to its disappearance in the Black Sea area.

\section{THE BLACK SEA HISTORY}

Based on geological and geophysical data, there are three long stages in the Black Sea history. The first stage in Mesozoic and Paleogene times is characterized by the complex of sedimentary formations in the median massif areas. The deep-sea trough of the Black Sea still did not exist during this period; instead there was a shallow-water basin.

The second stage (Oligocene-Miocene) coincides with the Alpian orogenic stage, when separate depressions were formed on the surface of the median massif within the contours of the present sea (Figure 6). These depressions were limited in area and rather thick strata of Maikop series (Oligocene and lower Miocene) and Miocene age accumulated in them. The Maikop series and the middle and upper Miocene deposits are widespread and reach $3-5 \mathrm{~km}$ in thickness at the Kerch and Taman peninsulas. Their accumulation probably took place within the northern margins of the same depressions which are detected (Muratov, 1972) southwards from the Crimea and Caucasus coast. Later these sediments were uplifted here, but they still remained submerged below the Black Sea.

The lower sections of Sites 380 and 381 have facies of black siltstones, which probably formed at the end of the second stage (late Miocene). The interbeds of dolostones included in the black siltstones are formed in a shallowwater environment and have undergone considerable subaerial diagenetic alterations (Stoffers and Müller, this volume).

In the pre-Bosporus era, the Black Sea was a shallowwater basin. Based on diatom data (Site 381) it was first fresh water, but then the conditions changed into a slightly brackish-water-marine phase, as indicated by the benthic

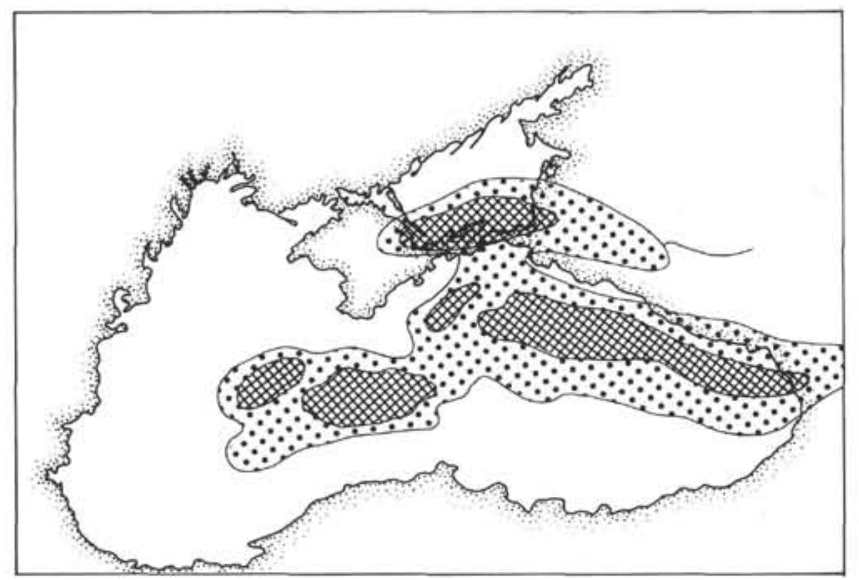

Figure 6. Outlines of the probable position of OligoceneMiocene orogenic basins in the floor of the Black Sea and Azov Sea, and within the surrounding coasts. The deepest troughs are hatchured. (After Muratov, 1972). foraminifers. The climatic regime was warm, and a large quantity of pine pollen is found in the sediments, as well as that of Engelhardtia flora. The sediment color is principally black and dark gray, and there are interbeds of different carbonates and zeolites. Pyrite and organic contents are enriched, and the lamination is not broken by burrows. This indicates that there were reducing conditions at the time in the basin. the recurrence of the sedimentation cycle was probably conditioned by fluctuations in the interface of the stratified waters (Degens and Stoffers, 1976).

During the Miocene the sedimentary material from Sites 380 and 381 is genetically linked with the volcanogenic rocks of the southwestern drainage area. Mineral composition, particularly high contents of well-crystallized montmorillonite, support this view (Stoffers and Müller, this volume, Trimonis et al., this volume). Brecciated horizons indicate a great inflow of marine waters from the Mediterranean Sea. The uplifting of the Black Sea water level and salinization of its waters are connected with this phenomenon. During the Miocene, the gradual subsidence of the bottom took place.

The third stage in the history of the basin is the formation of the Pliocene-Quaternary complex of sediments. During the Pliocene further subsidence of the Black Sea occurred and was accompanied by the accumulation of a thick strata of sapropelic-diatomaceous clays and Seekreide. Initially, the basin was slightly brackish-marine as indicated by nannofossils-Braarudosphaera bigelowi, microfauna Bolivina, as well as the complex of marine diatoms in olive-black clays. A cyclic recurrence of sediments indicates that the basin was, as before, stratified and the interface had repeated fluctuations. According to the pollen data, the climate remained warm. The cold stage took place considerably later, probably during the formation of the thick seekreide strata, which comprises about 200 meters (Unit III) at Holes 380/380A. There are fluctuations in the pollen spectrum indicating the presence of short warm intervals. Slightly cold periods also occurred before the beginning of the Pleistocene.

The facies change of the Pliocene sediments show the following sequence: olive-black diatomaceous clays (Unit $\mathrm{IV}_{\mathrm{c}}$, Site 380 , and Unit 7, Site 381) are covered by the seekreide facies consisting of fine laminated sediments. Marls contain numerous traces of burrows, indicating that the basin was well aerated at this time. Judging by the diatoms and dinoflagellates, the basin was being gradually freshened. Overlying diatomaceous sapropel-like clays suggest the return to reducing conditions. Separate interbeds of lithified siderite were formed under these conditions.

The next change of facies occurs with the formation of Unit III (Holes 380/380A) and Unit 4 (Site 381). The cyclic sedimentation pattern (interbeds of pyrite, mud, and calcite) shows that stratification of the basin waters occurred from time to time, though for the most part the Black Sea bottom waters were well aerated. This point is supported by numerous traces of burrows.

The seekreide facies at Site 380 are underlain by strata of dark clays including brown and microlaminated layers with siderite and fine interbeds of other carbonates. At the other sites the sediments synchronous to these are probably absent. The presence of siderite and dark greenish gray pyrite-rich layers suggest that the basin waters were periodi- 
cally stratified. The desalted basin changed to a slightly brackish-marine one, and was undoubtedly a deep-sea basin with subsidence still taking place. The bulk of sedimentary material, as indicated by mineral composition, was supplied from the south and southwest prior to the formation of Unit II (Site 380). A noticeable change was observed during the formation of Unit II, with an increase of illite, kaolinite, and chlorite; clastic dolomite is also present. This change may be directly linked with the major reorganization of the Black Sea river system in the drainage area. Prior to this time, the Danube probably did not discharge into the Black Sea and its sediment load was accumulated in other basin-traps (Trimonis and Shimkus, this volume; Hsü, this volume; Stoffers and Müller, this volume). The uplifting of the pre-Carpathian basins of Romania and the subsequent Danube discharge into the Black Sea considerably altered the balance of sedimentary material transported from the drainage area. The delivery of great amounts of terrigenous matter from the north resulted in sharp sedimentation changes, i.e., terrigenous sedimentation became predominant.

Pleistocene sediments at all three sites are mainly represented by terrigenous muds, silts, and fine sandy interbeds. According to the pollen data (Traverse, this volume), the climate periodically changed, and one may single out three cold and three warm intervals; but there is not definitive data to date or correlate these intervals with other stratigraphic sequences. The sedimentation conditions in the basin at this time were closely connected with the climatic fluctuations. The basin was transformed from a desalted one to a marine one due to the inflow of Mediterranean waters during the interglacial epochs. At that time, density stratification appeared and sapropelic muds were formed. During glacial periods the sea level dropped and terrigenous sedimentation was characterized by widespread turbidites. The sedimentation in the central part of the basin during a principal portion of the Quaternary depended on the amounts of sedimentary material amounts transported form the Pontic Mountains. Within these provinces volcanogenic rocks of basic composition and ultrabasics were widespread, and the Pleistocene sediments were enriched in montmorillonite and clinopyroxenes. Sedimentation in the western part of the basin, particularly in the Bosporus area, was mostly controlled by the Danube input. The paleogeographical environment of the basin during the Quaternary was determined mainly by climatic and tectonic phenomena.
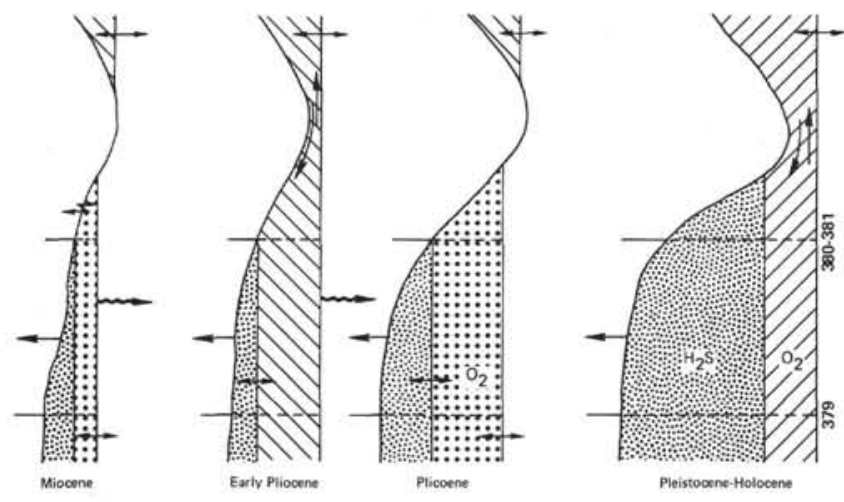

Figure 7. Black Sea evolution during late Cenozoic.

Black Sea evolution during the late Cenozoic is diagrammatically shown in Figure 7. During the Holocene, the shape and size of the basin was similar to the present one (The Earth's Crust, 1975). After the deep Würmian regression, sea level gradually rose, and during the old Black Sea period (middle Holocene) transgression reached its maximum the level exceeding the recent one by some meters. At that time ( 9000 years ago) the last salinization of the Black Sea began due to the resumption of water exchange with the Mediterranean Sea. During the late Black Sea period (upper Holocene, 0-3000 years) judging by the sediment composition, the sea level in the basin was essentially the same as that of the present.

\section{REFERENCES}

Arkhangelsky, A. D. and Strakhov, N. M., 1938. Geologicheskoe stroenie Chernogo morya. (Geological structure and history of development of the Black Sea): Academy of Science of USSR.

Degens, E. T. and Ross, D. A. (Eds.), 1974. The Black Seageology, chemistry, and biology:Am. Assoc. Petrol. Geol. Mem. 20, p. 633.

Degens, E. T. and Stoffers, P., 1976. Stratified waters as a key to the past: Nature, V. 263, p. 22-27.

Muratov, M. V., 1972. Istoriya formirovaniya glubokovodnoi kotloviny Chernogo morya v sravnenii $s$ vypadinami Sredizemnogo. (History of the formation of the Black Sea deepwater basin in comparison with the Mediterranean depressions). Geotektonika, no. 5, p. 22-41.

The Earth's Crust and the History of the Development of the Black Sea Basin, 1975: Moscow (Nauka). 